\title{
JAK MOŻLIWA JEST ADAPTACYJNA ANALIZA SZTUKI? NIEKTÓRE PROBLEMY METODOLOGICZNE ESTETYKI EWOLUCYJNEJ
}

\begin{abstract}
Streszczenie. Estetyka ewolucyjna jako młoda i obiecująca dyscyplina nadal w zasadzie nie posiada wypracowanej metodologii, choćby takiej jak neuroestetyka. Na przykład spory wokół tego, kiedy dane zachowanie artystyczne można uznać za adaptację (a może produkt uboczny adaptacji lub twór wyłącznie kulturowy), nie prowadzą do jasnych konkluzji, co wynika z faktu, że otrzymywane wyniki badań można często przypisać do wielu hipotetycznych funkcji. Z kolei, jeśli hipoteza o tym, że dane zachowanie jednoczy ludzi, zostanie potwierdzona empirycznie, to i tak nie musi to oznaczać, że zachowanie to jest adaptacją. Aby wyjaśnienie ewolucyjnego pochodzenia zachowania było wiarygodne, powinno ono przejść test Tinbergena (1951), a więc uzyskać potwierdzenie w każdym z czterech aspektów: (1) powinno ujawniać się spontanicznie na wczesnym etapie rozwoju osobniczego, (2) posiadać zidentyfikowaną funkcję oraz (3) historię ewolucyjną, a także (4) mechanizm emocjonalny wywołujący przyjemność lub odrazę, który uruchamia się w określonych okolicznościach. Jeśli każdy z tych warunków zostanie spełniony, z dużą dozą pewności można stwierdzić, że badane zachowanie jest adaptacją w sensie ścisłym. Czy jednak ścisłość jest domeną sztuki? W artykule starano się dowieść, że wyjątkowa idea konsiliencji nauk humanistycznych i przyrodniczych, pomimo licznych wątpliwości metodologicznych, w badaniach estetyków ewolucyjnych znajduje atrakcyjną z punktu widzenia współczesnych, uniwersalistycznych wyzwań, wykładnię. Pozwala też zbliżyć nas do zrozumienia wyjątkowości człowieka - jedynego gatunku, który powszechnie tworzy i konsumuje sztukę, będąc w niej bezgranicznie rozmiłowany.
\end{abstract}

Słowa kluczowe: sztuka, ewolucja, adaptacja, dobór płciowy, konsiliencja

1. Wstęp. 2. To tylko teoria... 3. Ewolucyjne badanie sztuki. 4. Darwin, sztuka i dobór płciowy. 5. Zarzuty wobec podejścia ewolucyjnego. 6. Poziomy wyjaśnienia funkcjonalnego w adaptacyjnej analizie sztuki. 7. Podsumowanie. 


\section{WSTĘP}

Czy sztuka jest ewolucyjną adaptacją ludzkiego umysłu, taką jak strach przed pająkami czy zdolność widzenia głębi? Czy możemy mówić o uniwersalnych wyznacznikach estetycznych ukształtowanych przez dobór naturalny i płciowy? Tego rodzaju pytania formułowane są od niedawna na gruncie estetyki ewolucyjnej - młodej dyscypliny w obrębie estetyki filozoficznej, zainspirowanej teorią ewolucji Darwina i jej współczesnymi rozwinięciami. Kluczowe dla zrozumienia istoty sporów wokół adaptacyjnej funkcji sztuki jest pojęcie adaptacji biologicznej. W swych rozważaniach estetycy ewolucyjni poddają je analizie na równi z pojęciem sztuki, starając się dowodzić jednocześnie, że teoretyczne ujęcie sztuki ulega przemianie pod wpływem ustaleń ewolucyjnych nauk o człowieku, poprzez stopniowe odejście od perspektywy estetycznej do naturalistycznej i natywistycznej.

Celem artykułu jest ukazanie, jak perspektywa ewolucyjna wzbogaca nasze pojęcie sztuki oraz, że może być ona ożywcza dla estetyki w obliczu jej kryzysu. Dowodzę również, że w hipotezach formułowanych na gruncie estetyki ewolucyjnej, mimo pewnych trudności metodologicznych, postulowana przez C.P. Snowa i E.O. Wilsona wyjątkowa idea konsiliencji (consilience) nauk humanistycznych i przyrodniczych znajduje atrakcyjną, z punktu widzenia współczesnych uniwersalistycznych wyzwań, wykładnię.

\section{TO TYLKO TEORIA...}

„Powie mi ktoś, że to tylko teoria. Niewątpliwie, jest to teoria naukowa i jako taka nie jest bezwzględnie pewna. W zasadzie mogłoby być także całkiem inaczej. Tylko że w obecnym stanie naszej wiedzy niepodobna rozsądnie w jej prawdziwość wątpić, tak mniej więcej, jak nie można wątpić, że Ziemia obraca się wokoło Słońca, choć teoria śp. ks. kanonika Kopernika jest także tylko teorią. Powiedziałbym, że mało jest w zoologii poglądów równie dobrze uzasadnionych 
jak ten"1. Tak o teorii ewolucji pisał w eseju Przeciw humanizmowi Jan Maria Bocheński, dominikanin, profesor Uniwersytetu we Fryburgu i jeden $z$ najbardziej zasłużonych w świecie polskich logików i filozofów. Kreśląc w nim swoje poglądy „na tak zwaną naturę człowieka”, poddał przy okazji dogłębnej krytyce trzy poglądy, które łączą się z koncepcją humanizmu (którą określa żartobliwie „człowiekochwalstwem"): że człowiek jest istotą wyższą, czyli bogatszą, lepszą, godniejszą od innych istot w świecie; że owa wyższość jest nie tylko ilościowa, ale także jakościowa: „człowiek ma nie tylko więcej inteligencji niż małpa, ale całkiem inny, wyższy rodzaj inteligencji”; oraz że człowiek jest czymś jedynym w swoim rodzaju, że żyje wprawdzie w świecie, ale nie jest częścią przyrody, że jest uważany „za wcielenie jakiejś wartości sakralnej”2.

Choć darwinowska teoria ewolucji jest dzisiaj w naukach przyrodniczych nieomal powszechnie akceptowana, to jej zastosowanie do badania mechanizmów życia społecznego i umysłowego rodzaju ludzkiego pozostaje wciąż w fazie początkowej ${ }^{3}$. Choć człowiek podlega niezmiennie procesom ewolucyjnym na wielu poziomach (zarówno genotypowym, jak i fenotypowym), analizowanie go w ten sam sposób, co inne stworzenia, u znacznej części humanistów natrafia na znaczny opór. Pierwszą współczesną dyscypliną, która dokonała tego

1 J.M. Bocheński, Przeciw humanizmowi, w: Sens życia i inne eseje, Kraków 1993, 32.

2 Por. tamże, 25-26.

3 Warto przy tym zauważyć, że również inni myśliciele związani z Kościołem zwracają uwagę na doniosłość teorii ewolucji, co może świadczyć o interdyscyplinarnym konsensusie w kwestii naukowości i uniwersalności praw ewolucji biologicznej. Można w tym miejscu wspomnieć choćby Przesłanie do członków Papieskiej Akademii Nauk Jana Pawła II z 1996 r., w którym polski papież pisał: „Nowe zdobycze nauki każą nam uznać, że teoria ewolucji jest czymś więcej niż hipotezą. Zwraca uwagę fakt, że teoria ta zyskiwała stopniowo coraz większe uznanie naukowców w związku z kolejnymi odkryciami dokonywanymi w różnych dziedzinach nauki. Zbieżność wyników niezależnych badań - bynajmniej nie zamierzona i nie prowokowana - sama w sobie stanowi znaczący argument na poparcie tej teorii". https://nauka.wiara.pl/doc/469395.Magisterium-Kosciola-wobec-ewolucji (dostęp: 31.01.2020). 
rodzaju „odsakralizowania”, prowadząc badania z uwzględnieniem perspektywy biologicznej, była etologia. Etologowie interesowali się czterema kluczowymi zagadnieniami w badaniu nad zachowaniami człowieka, które określa się czasem jako cztery wielkie pytania Tinbergena ${ }^{4}$. Są to pytania o to: (1) jak wygląda zachowanie i jakie są jego bezpośrednie przyczyny, (2) w jaki sposób zachowanie przyczynia się do wzrostu szansy przeżycia osobnika i przekazania jego genów następnym pokoleniom, a więc o cel adaptacyjny, który wydają się ono spełniać, (3) jakie są jego ewolucyjne lub filogenetyczne źródła, czyli jak mogła wyglądać ewolucja zachowania się, która doprowadziła do wyłonienia się analizowanej jego formy, a więc jego przyczyny pośredniej i w końcu (4) jego przyczyny rozwojowej, czyli w jaki sposób zachowanie rozwija się w trakcie ontogenezy osobnika ${ }^{5}$. Poszukiwanie odpowiedzi na wszystkie z tych pytań (przy wykorzystaniu paradygmatu psychologii ewolucyjnej, opierającego się przede wszystkim na teorii dostosowania łącznego, teorii doboru krewniaczego, sprecyzowanym pojęciu adaptacji, teorii altruizmu odwzajemnionego i teorii inwestycji rodzicielskiej) pozwala dziś określać, czy dane zachowanie ludzkie jest adaptacyjne w sensie biologicznym (czy też jest produktem ubocznym innych adaptacji umysłowych, a może technologią kulturową).

Teoria ewolucji, której założenia przyczyniły się do obecnego sukcesu nauk przyrodniczych, w tym etologii (oraz jej współczesnej wersji - psychologii ewolucyjnej), choć z wolna przebija się do świadomości przedstawicieli nauk humanistycznych i społecznych, wciąż pozostaje raczej źródłem pojedynczych inspiracji niż rzeczywistego wpływu. Nie zmienia to faktu, że perspektywa ewolucyjna zatacza

4 N. Tinbergen, On aims of ethology, Zeitschrift fur Tierpsychologie 20(1963), 410-433, por. D. Buss, Psychologia ewolucyjna, tłum. z ang. M. Orski, Gdańsk 2001, 33-34.

5 Por. T. Kaleta, Etologia klasyczna i jej filozoficzne oraz psychologiczne źródła, Życie Weterynaryjne 93(2018)8, 532-536. 
coraz szersze kręgi ${ }^{6}$. Jej zasięg oddziaływania można zaobserwować $\mathrm{w}$ wielu dyscyplinach oraz podejmowanych $\mathrm{w}$ ich obrębie zagadnieniach ${ }^{7}, \mathrm{w}$ tym także w estetyce, oraz w filozoficznych analizach sztuki ${ }^{8}$.

\section{EWOLUCYJNE BADANIE SZTUKI}

Ewolucyjne badanie sztuki rozpoczęło się w momencie, gdy powstała darwinowska biologia ewolucyjna. W 1857 r. Herbert Spencer opublikował pracę zatytułowaną Pochodzenie i funkcja muzyki, w której proponuje, aby tworzenie muzyki przez ludzi ściśle powiązać z rozwojem mowy. Doprowadziło to do dyskusji z Karolem Darwinem, który w O pochodzeniu cztowieka i Doborze ptciowym (1871) skłaniał się ku poglądowi, że muzyka z dużym prawdopodobieństwem była oparta filogenetycznie na odgłosach wydawanych przez różne zwierzęta podczas zalotów i że tak emocjonalne dźwięki poprzedzały rozwój mowy u ludzi. Parry ${ }^{9}$ zaproponował, aby wspólna ocena dzieł sztukifunkcja, która dziś powinna być określana jako współdzielona uwaga (shared attention $)^{10}$ - miała swe źródło w zbiorowych emocjach i ekscytacji, towarzyszącym grupom w sytuacjach takich jak polowanie. Allen, koncentrując się dodatkowo na elementach graficznych, takich

6 Por. M. Miłkowski, Perspektywy ewolucjonistyczne w badaniach społecznych, w: Oprogramowanie rzeczywistości społecznej, red. M. Gdula, L.M. Nijakowski, Warszawa 2014, 185-208.

7 Np. w psychologii (emocje, motywacje, agresja, empatia), socjologii (czynniki spójności społecznej, role społeczne), antropologii (uniwersalia kulturowe i gatunkowe), ekonomii (konsumpcja na pokaz), politologii (natura temperamentów politycznych), psycholingwistyce (pochodzenie i funkcja języka) czy w literaturoznawstwie i krytyce (powtarzające się motywy przewodnie i uniwersalia estetyczne).

8 Por. D. Dutton, Instynkt sztuki. Piękno, zachwyt i ewolucja człowieka, tłum. z ang. J. Luty, Kraków, 2019; J. Luty, Sztuka jako adaptacja. Uniwersalizm w estetyce ewolucyjnej, Kraków 2018.

9 Por. C.H. Parry, The Evolution of the Art of Music, London 1896.

10 Por. E. Dissanayake, Homo Aestheticus: Where Art Comes From and Why, Seattle 1995; B. Boyd, On the Origin of Stories: Evolution, Cognition, and Fiction, Cambridge, MA, 2009. 
jak symetria czy prymitywne kształty, zakładał, że nasza skłonność do tego typu przedstawień może wynikać z konstrukcji naszego mózgu, który ma tendencję do poszukiwania prawidłowości w otaczającym nas świecie, nawet tam gdzie ich nie $\mathrm{ma}^{11}$.

Te i inne pomysły, znacznie wyprzedzające nowoczesną neurobiologię, trafnie przewidywały wiele istotnych kwestii, które mają kluczowe znaczenie dla zrozumienia natury naszego zmysłu estetyki i przyjemności, płynącej z odbioru dzieł sztuki. W odniesieniu do wyobraźni figuratywnej James Sully uważał, że możemy preferować te obrazy, które sugerują podobieństwo do nas samych lub do natury $^{12}$, z kolei Alfred C. Haddon, który łączył ewolucyjne pomysły $\mathrm{z}$ antropologią $\mathrm{i}$ socjologią, sugerował ${ }^{13}$, że funkcje sztuki spełniane wśród tzw. ludów prymitywnych wskazują na ewolucyjne powody istnienia sztuki w ogóle ${ }^{14}$.

W ostatnich dziesięcioleciach w ramach ewolucyjnego podejścia do sztuki wysunięto wiele interesujących teorii i hipotez. Sztuka znalazła się w orbicie zainteresowań najważniejszych przedstawicieli współczesnych badań ewolucyjnych nad ludzkim zachowaniem (takich jak: Edward O. Wilson, David Buss, Leda Cosmides, John Tooby, Steven Pinker). Wilson w książce Konsiliencja z 1998 roku poświęcił sztuce osobny rozdział, co przyczyniło się do wzrostu zainteresowania jej obecnością w ewolucyjnej historii ludzkiego gatunku oraz w studiach nad ludzkim zachowaniem ${ }^{15}$. Jak zauważa Ellen Dissanayake, pomimo że etologowie również poświęcali swą uwagę sztuce, czynili to zwykle w bardzo pośredni sposób. Kwestia adaptacyjnych własności sztuki rzadko była poruszana wprost, pojawiając się jedynie w kontekście wyjaśnień ewolucyjnych innych zachowań i funkcji, takich

11 Por. G. Allen, Physiological Aesthetics, London 1877; tenże, The Colour-Sense: Its Origin and Development, London 1879.

12 Por. J. Sully, Art and Psychology, Mind 4(1876)1, 467-478.

13 Por. A.C. Haddon, Evolution in Art, New York 1914.

14 Por. N.E. Aiken, The Biological Origins of Art, Westport, Connecticut 1998.

15 E.O. Wilson, Konsiliencja. Jedność wiedzy, tłum. z ang. P. Mikos, Poznań 2002. 
jak: komunikacja, zdobywanie prestiżu, zabawa, potrzeba jedności i porządku, poszukiwanie, rozrywka i inne ${ }^{16}$.

\section{DARWIN, SZTUKA I DOBÓR PŁCIOWY}

Darwin postrzegał ludzką sztukę wizualną jako konsekwencję instynktu zdobienia ciał. Zwracał uwage na to, że samce w większości kultur pozwalają sobie na dużo większą swobodę, jeśli chodzi o ozdabianie samych siebie niż samice, tak jak przewiduje teoria doboru płciowego. (Rozumiał, że mężczyźni należący do jego własnej kultury zdobili się posiadłościami czy skarbami kolonialnymi raczej niż tatuażami i nakryciami na penisy) ${ }^{17}$.

W Doborze ptciowym formuluje pogląd (1871), że altany altanników (ptilonorhynchidae), rodziny ptaków, występujących w Australii i Nowej Gwinei, ewoluowały jako ornamenty zalotów dzięki doborowi płciowemu, dokonywanemu wraz z wyborem samic. Jest to myśl zupełnie przełomowa, ponieważ przenosi ciężar kierowania procesem ewolucyjnym $z$ samców na ich partnerki reprodukcyjne. Altany zachęcają samice do kopulacji poprzez reklamę sprawności samca i nie spełniają żadnej funkcji przetrwania ${ }^{18}$. Darwin określił

16 Por. E. Dissanayake, dz. cyt., 42-45.

17 Ciekawy opis z zakresu międzygatunkowej etologii porównawczej, który wyszedł spod pióra Darwina, zawiera np. następujący fragment: „Zarówno w wypadku ozdób sztucznych, używanych przez ludzi dzikich i cywilizowanych, jak i naturalnych upiększeń ptasich, przyozdabiana jest przede wszystkim głowa. (...) upiększenia są zadziwiająco zróżnicowane. Upierzenie czoła lub tyłu głowy składa się z piór ukształtowanych rozmaicie; czasami mogą się one podnosić lub rozpościerać, przez co w pełni ujawniają się ich piękne barwy. (...) Również gardło przyozdobione jest czasami brodą, koralami lub wyrostkami mięsnymi. Takie przydatki bywają na ogół ubarwione jaskrawo i niewątpliwie stanowią ozdobę". K. Darwin, Dobór płciowy, tłum. z ang. K. Zaćwilichowska, Warszawa 1960, 184. Por. też G. Miller, Aesthetic fitness: How sexual selection shaped artistic virtuosity as a fitness indicator and aesthetic preferences as mate choice criteria, Bulletin of Psychology and the Arts, Special issue on evolution, creativity, and aesthetics 2(2001)1, 20-25.

18 Por. G. Miller, art. cyt., 20-25. 
altannika jako gatunek, który „nabył dziwnego instynktu budowania altanek dla pląsów miłosnych"19.

Angielski przyrodnik zdawał sobie sprawę, że altany są jednym z najlepszych przykładów doboru płciowego oraz sztuki tworzonej przez zwierzęta. Altany pokazują, że wybór dokonywany przez partnerkę może stworzyć skomplikowane adaptacje psychologiczne do konstruowania estetycznych ornamentacji poza ciałem zwierzęcia (Richard Dawkins określi je potem jako fenotyp rozszerzony). Altany pokazują również, że dobór płciowy faworyzuje sprawność. Estetyczna jakość altany jest wiarygodnym wskaźnikiem nieprzeciętnych umiejętności, sprawnego mózgu, dobrych genów, a samice altannika rozwinęły estetyczny zmysł oceny po to, by rozróżniać altany w celu uzyskania najlepszych genów (dziedzicznej sprawności) dla swojego potomstwa ${ }^{20}$. Koncepcja pokazu sprawności znalazła potwierdzenie w tzw. hipotezie upośledzenia (handicap principle), sformułowanej przez Amotza Zahaviego, mówiącej o tym, że koszty poniesione na pokaz same w sobie są pokazem sprawności ${ }^{21}$.

$\mathrm{Na}$ problem $\mathrm{z}$ aplikacją reguły pokazu sprawności do zalotów u ptaków zwraca uwagę Richard O. Prum ${ }^{22}$. Według tego ornitologa, altana altannika jako rozszerzony fenotyp samca podlegający ocenie samicy jest pokazem zbyt skompilowanym, aby umożliwiał jednoznaczną ocenę sprawności potencjalnego partnera (podobnie jak fantastycznie zdobiony i prezentowany $\mathrm{w}$ niezwykle energicznym pokazie ogon argusa malajskiego). Gdyby hipoteza wyboru w oparciu o uczciwe sygnały pokazu sprawności była prawdziwa,

19 K. Darwin, dz. cyt., 182.

20 Por. tamże, 182-183; por. G. Miller, art. cyt.

21 A. Zahavi, A. Zahavi, The Handicap Principle - A Missing Piece of Darwin's Puzzle, New York 1997.

22 Por. R.O. Prum, Ewolucja piękna. Jak darwinowska teoria wyboru partnera kształtuje świat zwierząt i nas samych, tłum. z ang. K. Skonieczny, Kraków 2019; przykładem estetycznego pokazu godowego jest także według Darwina i Pruma ogon argusa malajskiego (argusianus argus), por. K. Darwin, dz. cyt., 433. 
samiczka - która, zanim dokona matrymonialnego wyboru, odwiedza nawet osiem altanek, często bardzo od siebie oddalonych (a więc naraża się na niebezpieczeństwo) - musiałaby dysponować przeogromnym repertuarem ocen dla poszczególnych ich elementów, które to oceny przekładałyby się następnie na rozpoznawanie określonych sprawności, jakie dany element pokazu miałby reprezentować, co wydaje się przerastać zdolności percepcyjno-poznawcze nie tylko ptaka, ale każdego innego stworzenia. Prum uważa, i jest to hipoteza samego Darwina, że zachowanie altannika (a także argusa malajskiego), które pierwotnie ewoluowało jako pokaz sprawności, tak by wybierane były cechy stanowiące uczciwe i trafne wskaźniki zdrowia, wigoru i zdolności przetrwania, z czasem ewoluowało do postaci sygnału estetycznego, który jest odczytywany w oderwaniu od swej pierwotnej funkcji. „(...) siłą, która napędza późniejszą ewolucję wyboru partnera jest sam wybór partnera (...) arbitralne wybory estetyczne (Darwina) okazują się istotniejsze niż wybory dokonywane ze względu na przewagę adaptacyjną (Wallace’a), ponieważ cecha, która oryginalnie była preferowana $\mathrm{z}$ powodu adaptacyjnego, stała się samodzielnym źródłem atrakcyjności. Kiedy cecha staje się atrakcyjna, jej atrakcyjność i popularność stają się celami samymi w sobie"23.

Ocena dokonywana przez samice altannika i argusa nie ma zatem charakteru funkcjonalnego (nie polega wyłącznie na właściwym odczytaniu pokazu sprawności), lecz estetyczny, subiektywny i jest wyrazem wolności czy wręcz dowolności wyboru. Należy zgodzić się z autorem, że przywykliśmy uważać zachowania zwierząt za bardziej zdeterminowane genetycznie niż zachowania ludzi. Być może powinniśmy zrewidować ten pogląd.

Łączenie przez Darwina ludzkiej aktywności artystycznej z ekstrawaganckim pokazem, pełniącym funkcję zalotów u innych zwierząt, było podejściem oryginalnym i trafnym, opartym na ważnych przesłankach teoretycznych. $Z$ punktu widzenia teorii estetycznej 
kilka elementów wymagałoby jednak uściślenia. Po pierwsze, Darwin operował XIX-wiecznym pojęciem sztuki, które łączyło ją z pięknem jako jej nieodłączną cechą. Tymczasem zarówno badacze XX-wiecznej sztuki modernistycznej, jak i różnych odmian sztuki niskiej niekoniecznie odwołują się do elitarnego estetyzmu sztuk pięknych. Piękno nie jest ani pojęciem uniwersalnym, ani jednoznacznym: rozumienie go jako to, co harmonijne zawęża jego znaczenie, natomiast w znaczeniu szerokim jest bardziej wyrazem zachwytu niż określeniem cechy definiującej sztukę.

Po drugie, jest raczej wątpliwe, aby płeć żeńska ludów pierwotnych (w przeciwieństwie do altannika i argusa malajskiego) dokonywała wyborów seksualnych wyłącznie na podstawie piękna czy sztuki. $\mathrm{Z}$ pewnością z punktu widzenia kobiet nie mniej istotne u potencjalnych partnerów reprodukcyjnych powinny być takie cechy, jak wytrzymałość, wytrwałość czy siła charakteru, a więc różne pozaestetyczne odmiany pokazów sprawności. To zastrzeżenie można zresztą spróbować odnieść do całego projektu traktującego sztukę jako „pokaz sprawności”. Sztuka wedle tego podejścia nie różni się zasadniczo od każdego innego rodzaju aktywności, który wymaga nakładów energii, czasu i zasobów, trwonionych bez wyraźnego celu adaptacyjnego (np. kupna drogiego samochodu, zorganizowania wystawnego przyjęcia, przebiegnięcia maratonu). Po trzecie, pojęcie sztuki, które interesuje etologa, na przykład Ellen Dissanayake, jest znacznie szersze i obejmuje, oprócz wizualnego pokazu, również muzykę, taniec, zdobienie otoczenia, czy opowiadanie historii (połączone nierzadko w jeden multimedialny protoperformens) ${ }^{24}$.

Teoretycy tego okresu, którzy stosowali optykę ewolucyjną, ale nie brali na serio teorii doboru płciowego, mieli problem ze zrozumieniem adaptacyjnej funkcji sztuki, z jej kosztami energetycznymi oraz ograniczonymi możliwościami przetrwania, wynikającymi z tych kosztów. Na przykład Ernst Grosse pisał w Początkach sztuki, że

24 Por. E. Dissanayake, dz. cyt., M. Kocur, Źródła teatru, Wrocław 2013, 150-220. 
dobór naturalny odrzuciłby ,już dawno, ludzi, którzy tracili swe siły w tak bezcelowy sposób [t.j. tworzenie dzieł sztuki], na rzecz ludzi o praktycznych talentach; zatem sztuka nie mogła była rozwinąć się tak bardzo i obficie, jak to się stało" 25 . Opinię tę podzielali tacy darwinowscy teoretycy sztuki przełomu XIX i XX w. jak Henry Balfour, A.C. Haddon i Felix Clay, poszukując przede wszystkim wiele wiarygodnych nieseksualnych funkcji sztuki ${ }^{26}$.

Takie podejście wynikało w znacznej mierze z niewłaściwego zrozumienia mechanizmów doboru płciowego oraz ogólnych zasad teorii ewolucji. W owym czasie popularne było, wywodzące się od Herberta Spencera materialistyczne rozumienie mechanizmów ewolucyjnych, które operowało terminami walki o byt (struggle for existence) czy przetrwania najlepiej przystosowanych (survival of the fittest) ${ }^{27}$, co powodowało, że skupiano się przede wszystkim na męskiej rywalizacji, w niej upatrując motor napędowy doboru płciowego ${ }^{28}$. Jak zauważa Miller, „przez ponad wiek, dobór płciowy był postrzegany jako mechanizm oparty o męską rywalizację, w którym aktywne, konkurujące ze sobą samce walczyły o "posiadanie« biernych samic, poprzez zdobywanie terytorium i pozycji oraz odpieranie rywali" 29 .

25 E. Grosse, The Beginnings of Art, New York - London 1914, 312; por. G. Miller, art. cyt.

26 Por. G. Miller, art. cyt.

27 Problem z użyciem terminu survival of the fittest, który Darwin zapożyczył od Herberta Spencera, polega na tym, że choć jest ono lepsze od całkowicie błędnego stosowania terminu survival of the strongest (przeżycie najsilniejszych), to wciąż nie oddaje istoty działania procesu ewolucyjnego. Bardziej właściwe jest mówienie o reproduction of the fittest (rozmnażaniu się najlepiej przystosowanych), ponieważ najważniejszym miernikiem sukcesu ewolucyjnego jest wydanie na świat potomstwa (czego samo przeżycie osobników jeszcze nie gwarantuje, choć jest do tego koniecznym warunkiem), co nie zawsze dotyczy osobników najsprawniejszych, lecz na przykład tych, które wykażą się najbardziej ekstrawaganckim pokazem (zgodnie z logiką doboru płciowego).

28 Por. H. Cronin, The Ant and the Peacock: Altruism and Sexual Selection from Darwin to Today, Cambridge 1991; G. Miller, Umysł w zalotach, tłum. z ang. M. Koraszewska, Poznań 2004.

29 G. Miller, Aesthetic fitness, art. cyt. 
Nie brano raczej pod uwagę możliwości, że to samice dokonują wyboru partnera i że może się to odbywać na podstawie kryteriów estetycznych. Co ciekawe, ornamenty uważano zwykle (wbrew poglądom samego Darwina) za wskaźniki przynależności do danego gatunku, które miały rzekomo pomagać zwierzętom w unikaniu kopulacji międzygatunkowej. Dopiero w ostatnich kilku dekadach, m.in. za sprawą odkryć Roberta Triversa i sformułowanej przez niego teorii różnic w inwestycji rodzicielskiej samców i samic czy wspomnianej hipotezy upośledzenia Zahaviego, pogląd ten uległ zmianie. Dobór płciowy uważa się obecnie za istotny, a zdaniem takich autorów jak Geoffrey Miller czy David Buss, za podstawowy czynnik regulujący ewolucję ludzkich ciał i umysłów, sygnałów i interakcji społecznych, również w odniesieniu do sztuki.

Nawet jeśli niektórzy XIX-wieczni teoretycy nie ulegali spencerowskiej wersji darwinizmu i pochylali się na teorią doboru płciowego $\mathrm{w}$ odniesieniu do sztuki, jak Felix Clay w The Origin of the Sense of Beauty, to popełniali zazwyczaj typowy błąd utożsamiania funkcji seksualnych z pobudkami seksualnymi. Jest to zresztą dość częste przeoczenie, pojawiające się również $\mathrm{w}$ niektórych współczesnych analizach. Aby przyciągać potencjalnego partnera, sztuka nie musi traktować bezpośrednio o seksie, podobnie jak zdobienie altany przez altannika nie musi być emocjonalnie umotywowane pragnieniem kopulacji ${ }^{30}$. Namalowanie obrazu, napisanie sonetu czy przyozdobienie gniazda - wszystkie te czynności są zindywidualizowanymi pokazami sprawności, w którym osobnik sprawniejszy robi większe wrażenie na potencjalnej partnerce lub uzyskuje wyższą ocenę w odbiorze społecznym od osobnika mniej sprawnego i dlatego działanie to można $\mathrm{z}$ powodzeniem opisać w kategoriach doboru płciowego.

30 Przypomina to jedno z powszechnych nieporozumień na temat teorii Darwina, a mianowicie, że z reguł ewolucji wynika bezpośrednia motywacja do maksymalizowania reprodukcji swoich genów (dlaczego tak nie jest, wyjaśniam dalej, omawiając klasyczne zarzuty formułowane wobec podejścia ewolucyjnego). 
Jednak ani sonet, ani obraz nie musi mieć charakteru erotycznego. Jak zauważa Miller, fakt, że „niektóre altanniki budują altanki wysokie i stożkowate jak fallus, [a] inne budują altanki w kształcie jajek, które wyglądają jak joni, (...) to zwykły zbieg okoliczności”31.

\section{ZARZUTY WOBEC PODEJŚCIA EWOLUCYJNEGO}

Wobec podejścia ewolucyjnego w naukach humanistycznych (w tym w naukach o sztuce) formułowanych jest wiele zarzutów (listę powszechnych nieporozumień na temat teorii ewolucji zestawia David Buss i inni) ${ }^{32}$. Można je podzielić na powszechne nieporozumienia dotyczące teorii ewolucji oraz bardziej sensowne zarzuty formułowane z jednej strony wobec psychologii ewolucyjnej, z drugiej zaś wobec ewolucyjnych studiów nad sztuką.

Do pierwszej grupy należą m.in.: przekonania, że zachowanie ludzkie jest zdeterminowane genetycznie; że jeżeli coś powstało na drodze ewolucji, to znaczy, że nie jest podatne na zmiany; że obecnie działające mechanizmy psychologiczne są optymalne i że $z$ teorii ewolucji wynika bezpośrednia motywacja do maksymalizowania reprodukcji swoich genów ${ }^{33}$. Pierwsze $z$ nich określa się mianem determinizmu genetycznego i opiera się na błędnym przekonaniu, że geny wywołują określone zachowania bez wpływu ze strony środowiska. W rzeczywistości zachowanie jest wypadkową obu czynników:

31 G. Miller, Umysł w zalotach, dz. cyt., 307.

32 D. Buss, dz. cyt., 40-44; M. Miłkowski, dz. cyt., 185-208; M. Hohol, Wyjaśnić umysł. Struktura teorii neurokognitywnych, Kraków 2013.

33 To dość częsty błąd mylenia motywów i celów działania z odpowiedzialnymi za nie procesami. Buss ilustruje go, przytaczając przykład badania psychologicznego, w którym proszono ludzi, aby napisali, czym się aktualnie zajmują. Niektórzy mówili o rzeczach błahych, jak „uczenie kota załatwiania się w przeznaczonym do tego miejscu albo zapuszczanie paznokci”. Innych zaprzątały większe sprawy, „jak uzyskanie dyplomu, nawiązanie znajomości, a nawet wprowadzenie zmian w cywilizacji zachodniej”. Przez 20 lat tych badań nie znalazł się jednak nikt, kto by odpowiedział: „dążę do maksymalizacji reprodukcji moich genów"; por. D. Buss, dz. cyt., 43. 
ewolucyjnych adaptacji oraz wpływu środowiska. Na potwierdzenie prawdziwości tej oczywistej zasady Buss podaje przykład sposobu, w jaki powstają zrogowacenia skóry. Nie mogłyby one zaistnieć, gdyby nie wykształcił się mechanizm produkowania dodatkowego naskórka, połączony ze środowiskowym bodźcem w postaci częstych obtarć skóry. Tłumaczenie tego zjawiska przy użyciu terminologii ewolucyjnej przez stwierdzenie, że zrogowacenia są uwarunkowane genetycznie i występują niezależnie od wpływów środowiska jest zwyczajnie błędne. Jeśli nie ma obtarć, nie ma też zrogowaceń. Dopiero obecność obu czynników gwarantuje ekspresję cechy.

Niezbędność wpływu środowiska na wykształcenie się danej zdolności dobrze ilustruje przykład przyswajania mowy. Nie ma wątpliwości, że umiejętność posługiwania się językiem jest uwarunkowana ewolucyjnie, a specyficzna wersja genu FOX2 jest taka sama u wszystkich ludzi i różni się (wprawdzie nieznacznie) od jego wersji $\mathrm{u}$ innych naczelnych. Mowa wykształca się spontanicznie u każdego zdrowego dziecka. Nie uczy się ono mówić w ten sam sposób, w jaki uczy się czytać albo pisać, nie trzeba go do tego przymuszać, nabywanie mowy następuje w sposób odruchowy. Musi być jednak spełniony jeden niezbędny warunek - otoczenie, czyli obecność grupy społecznej. Dziecko wychowane w całkowitej izolacji i ,niewystawione" w odpowiednim momencie rozwoju na bodźce środowiskowe nie wykształci zdolności mówienia, nigdy też nie nadgoni straconego czasu. Sama obecność programu adaptacyjnego nie wystarcza.

Podobnie jest $z$ innymi cechami adaptacyjnymi, w tym psychologiczno-społecznymi. Dowiedziono na przykład, że istnieją różnice międzypłciowe w częstości przypisywania zamiarów seksualnych płci przeciwnej - kobiety robią to rzadziej od mężczyzn. Buss przywołuje badanie, w którym określano reakcję na uśmiech kierowany ze strony kobiet w kierunku mężczyzn. Jeśli kobieta uśmiechnie się do mężczyzny, obecni przy tym mężczyźni, częściej niż kobiety, uznają, że 
jest ona nim seksualnie zainteresowana ${ }^{34}$. Zdaniem Bussa, wynika to z ewolucyjnie wykształconego mechanizmu, który skłania kobiety do ostrożniejszego wyboru potencjalnych partnerów, co z kolei nie dotyczy mężczyzn, bo są oni bardziej zaprogramowani na poszukiwanie przelotnych okazji seksualnych ${ }^{35}$. Różnice w inwestycji rodzicielskiej (termin wprowadzony przez Triversa) ${ }^{36} \mathrm{u}$ obu płci przekładają się zatem na różnice $\mathrm{w}$ strategiach doboru partnera - kobiety wybierają ostrożniej, mężczyźni powierzchowniej (jednocześnie częściej próbując zaimponować potencjalnym partnerkom poprzez różnego rodzaju pokazy i popisy). A zatem mężczyźni częściej myślą o niezobowiązujących relacjach (właśnie z powodu mniejszej inwestycji rodzicielskiej). Jednak jak konkluduje autor, dopiero znajomość tego mechanizmu pozwala go zmienić. „Można na przykład nauczyć mężczyzn, że zbyt łatwo przypisują uśmiechającym się do nich kobietom intencje seksualne. Dzięki temu rzadziej będą podejmowali działania oparte na tej mylnej interpretacji i zmniejszą liczbę niepożądanych zalotów"37.

W podobnym duchu wypowiada się Helena Cronin, krytykując nastawione antydarwinowsko nurty feminizmu (utrzymujące, że równe traktowanie kobiet i mężczyzn będzie możliwe dopiero po dowiedzeniu ich biologicznej identyczności; a przecież to, że kobiety biologicznie różnią się od mężczyzn, nie oznacza, że powinny być nierówno traktowane). Brytyjska filozof stwierdza: „Jak w ogóle można sobie wyobrazić odpowiedzialną politykę nieopartą na wiedzy o różnicach między płciami? Przecież decyzje polityczne muszą bazować na rozumieniu natury ludzkiej, czyli zarówno męskiej, jak

34 Por. tamże.

35 Por. tamże.

36 Por. R. Trivers, Parental investment and sexual selection, w: Sexual Selection \& the Descent of Man, red. B. Campbell, New York 1972, 136-179.

37 Por. D. Buss, dz. cyt., 41. 
i żeńskiej”38 i dodaje: „Odpowiedź na genetyczny determinizm jest zatem prosta: chcesz zmienić zachowania, modyfikuj środowisko. A żeby wiedzieć, jakie zmiany mogą być sensowne i pożyteczne, trzeba znać prawa darwinizmu" 39 .

Inne błędne twierdzenie funkcjonujące $\mathrm{w}$ popularnym przekazie jest takie, że obecnie działające mechanizmy psychologiczne są optymalne. Opiera się ono na niezrozumieniu zasady ewolucyjnej inercji (opóźnienia) kształtowania się cech ${ }^{40}$. Gdyby twierdzenie to było prawdziwe, to dziś w społeczeństwach Zachodu nie cierpielibyśmy masowo na cukrzycę, otyłość i problemy kardiologiczne, a arachnofobię (intuicyjny strach przed pająkami) zastąpiłaby np. samochodofobia (samochody są częstszą przyczyną śmierci niż pająki czy węże). Spośród pozostałych należy wymienić choćby: błąd panadaptacjonizmu (czyli naiwny selekcjonizm), sprowadzanie ewolucji wyłącznie do doboru naturalnego (lub traktowania drugiej darwinowskiej siły selekcyjnej - doboru płciowego - jako odmiany pierwszej); błąd utożsamienia ewolucji z przetrwaniem najsilniejszych (klasyczny spencerowski socjodarwinizm, wynikający z niezrozumienia mechanizmów ewolucyjnych); przekonanie, że podmiotem ewolucji jest gatunek (a nie jednostka czy gen, co stało się przedmiotem słynnej Biologicznej Bzdury Roku 2013); lamarkizm, czyli przekonanie o dziedziczeniu cech nabytych (to prawda, że londyńscy taksówkarze mają powiększony hipokamp i że zmiany w objętości tego obszaru mózgu, odpowiedzialnego za pamięć, odbywają się w trakcie ich życia - co miało rzekomo dowodzić, że mechanizmy umysłowe nie powstają stopniowo w procesie ewolucji, ale że moga ulegać przeobrażeniom w trakcie ontogenezy; owszem, mogą, ale syn taksówkarza nie będzie natural born taxi driver); uznawanie

38 H. Cronin, Zrozumieć naturę człowieka, w: Nowy Renesans, red. J. Brockman, tłum. z ang. P.J. Szwajcer, A.E. Eichler, Warszawa 1996, 66-67.

39 Tamże, 60.

40 Por. B. Pawłowski, Adaptacje i ewolucyjna inercja ludzkiego umysłu, w: Ewolucja. Filozofia. Religia, red. D. Leszczyński, Wrocław 2010, 109-121. 
ewolucji za proces celowy (we właściwym zrozumieniu nie pomagają tu niestety personifikujące określenia ewolucji czy doboru, takie jak: kształtuje, faworyzuje, eliminuje itd.).

Inny zarzut odnosi się do metody „inżynierii odwrotnej” jako sposobu wyjaśniania w psychologii ewolucyjnej, której stosowanie może skutkować formułowaniem twierdzeń typu „narząd X powstał po to, aby rozwiązać problem Y", które jednak nie podaje kryterium wyboru jednego spośród wielu możliwych scenariuszy opisujących korzyści wynikające $z$ danej cechy. ${ }^{41}$ Zastrzeżenia budzi też model $\mathrm{SSSM}^{42}$, stworzony przez psychologów ewolucyjnych na potrzeby krytyki nauk społecznych, który, według określenia M. Hohola, przypomina słomianą kukłę, którą można atakować w prosty sposób ${ }^{43}$.

\section{POZIOMY WYJAŚNIENIA FUNKCJONALNEGO W ADAPTACYJNEJ ANALIZIE SZTUKI}

Wielu badaczy niezajmujących się teorią ewolucji na co dzień, a próbujących zmierzyć się z jej zastosowaniem do innych dziedzin, podkreśla, że tezy formułowane w jej ramach wydają się często kontrintuicyjne. Być może jest to wynikiem ateleologicznego charakteru działania doboru naturalnego oraz do pewnego stopnia płciowego ${ }^{44}$

41 Por. M. Hohol, dz. cyt., 122-123.

42 Standardowy Model Nauk Społecznych (Standard Social Sciences Model, czyli SSSM) określenie ukute przez Johna Tooby'ego i Ledę Cosmides - na określenie modelu dominującego w naukach społecznych, który zakłada, że osobowość człowieka jest wyłącznie produktem kultury ukształtowanym w procesie socjalizacji, a nasz umysł w chwili narodzin jest „czystą kartą”, która zostaje w toku wychowania „zapisana” przez środowisko. Zdaniem tych autorów, model ten w ostatnich latach zostaje zastępowany modelem ewolucyjnym, zgodnie z którym, jeśli pewne zachowania społeczne lub fakty kulturowe występują powszechnie, to można powiązać je z ewolucyjną adaptacyjnością oraz wskazywać na ich związek z darwinowskim mechanizmem doboru naturalnego lub płciowego; por. L. Cosmides, J. Tooby, dz. cyt.

43 Por. M. Hohol, dz. cyt., 123-124.

44 Kwestię ukierunkowania obu doborów w oryginalny sposób podejmuje Dutton, który zwraca uwagę, że dobór płciowy w pewien sposób rehabilituje celowość w teorii ewolucji 
oraz znacznego skomplikowania mechanizmów adaptacyjnych u ludzi. Jak pisze Dissanayake: „Indywidualności nie są w nieustającej walce między sobą: współczucie, hojność i współpraca są tak samo częścią ludzkiej natury jak interesowność, ksenofobia i agresja" ${ }^{45}$. Być może owa trudność ze zrozumieniem jest też wynikiem głęboko zakorzenionych przyzwyczajeń teoretycznych. Autorka Homo Aestheticus zwraca uwagę na pewien aspekt aplikacji ewolucjonizmu w naukach o człowieku, a mianowicie na stosowane przez ewolucjonistów funkcjonalnych wyjaśnień ludzkich zachowań, które niewiele mają wspólnego z antropologicznymi założeniami na temat funkcjonalizmu. Wyjaśnienia ewolucjonistyczne nie sugerują na przykład, że wszystkie części społeczeństwa są ze sobą powiązane albo że indywidualne zachowania $\mathrm{w}$ społeczeństwie pełnią pewne funkcje specyficzne w danym społeczeństwie. Współczesna antropologia fizyczna odrzuca pojęcie funkcji powstałe w oparciu o modele wyjaśniające Durkheima, Malinowskiego i Radcliffe-Browna. Te szeroko zakrojone interpretacje funkcjonalnego społeczeństwa i kultury zostają zastąpione mniej ambitnymi i bardziej skoncentrowanymi, zindywidualizowanymi badaniami. W przeciwieństwie do wyjaśnień funkcjonalistycznych: „pojęcie funkcji adaptacyjnej nie musi być sztywne, hierarchiczne czy deterministyczne ani nie zmusi pojedynczych przypadków zachowań (adaptacyjnych) funkcjonalnych, takich jak sztuka, do bycia zarezerwowanym wytacznie dla Zachodu. Wręcz przeciwnie - idea adaptacjonizmu jest taka, że zachowania są rozwiniętymi predyspozycjami, które mogą być wyrażone w różnych kulturowych $\mathrm{i}$ indywidualnych przejawach" ${ }^{46}$.

(por. D. Dutton, dz. cyt., 277-280), co szczególnie dobrze widać na przykładzie doboru płciowego u ludzi, który nazywa „samoudomowieniem”, por. D. Dutton, dz. cyt., 279.

45 E. Dissanayake, The Arts After Darwin. Does Art Have Origin and Adaptive Function, w: World Art Studies: Exploring Concepts and Approaches, red. K. Zijlmans, W. van Damme, Amsterdam 2008, 245. Tłum. z ang. J.L.

46 Tamże. 
Powyższe uwagi Dissanayake ukazują, moim zdaniem, źródło wielu nieporozumień, również metodologicznych, w ewolucyjnych studiach nad sztuką. Wzmiankowane przez nią subtelne, acz o istotnym znaczeniu, rozróżnienie, jest o tyle ważne, że tok myślenia adaptacjonistów wymaga wyjaśnień funkcjonalnych. Są to jednak wyjaśnienia, które zakładają, że określone cechy (np. anatomiczne) posiadają funkcje $\mathrm{w}$ takim znaczeniu, że ręce służą do dotykania i tworzenia, a oczy do patrzenia (a więc nie w sensie funkcjonalistycznym, lecz właśnie ewolucyjnym). Jak podkreśla Dissanayake, również takie zachowania jak uśmiech, śmiech, zabawa czy mowa oraz kategorie zachowań takie jak zaloty, zachowania godowe, rodzicielstwo, agresja czy dzielenie się żywnością posiadają funkcję adaptacyjną, a często nawet kilka funkcji. „W toku ewolucji, dzieci apatyczne i nietowarzyskie nie rozwijałyby się tak dobrze jak ich bardziej interakcyjni rówieśnicy, którzy lepiej przetrwaliby do dorosłości, przekazując swoje geny następnym pokoleniom" 47 .

Identyfikowanie adaptacyjnych zachowań wymaga dwóch poziomów funkcjonalnego wyjaśnienia - bezpośrednich (proximate) powodów zachowania (jego pozornej motywacji oraz natychmiastowego emocjonalnego lub psychologicznego efektu - zwykle sprowadza się to do reakcji - „czuję, że to dobre lub słuszne”) oraz ich ostatecznej (ultimate) wartości adaptacyjnej (selektywnej, przystosowawczej) ${ }^{48}$. Oczywiście ludzie nie żyją ze świadomą decyzją lub zamiarem przetrwania czy przekazania własnych genów następnym pokoleniom, co obrazuje przywołana wcześniej uwaga Bussa o 20-letnim badaniu tego, „czym ludzie aktualnie się zajmują”. Tym, co skłania ich do codziennego działania są bliższe emocjonalne pragnienia oraz satysfakcje, które motywują i nagradzają adaptacyjne zachowania, takie jak zaloty i łączenie się w pary, opieka nad dziećmi, obrona

47 Tamże.

48 Powody bezpośrednie odpowiadają dwóm pierwszym przyczynom Tinbergena, powody ostateczne - dwóm ostatnim. 
przed agresorem, dzielenie się jedzeniem $\mathrm{z}$ własną rodziną $\mathrm{i}$ bliskimi, a także udział w tworzeniu sztuki. Te pragnienia i przyjemności, produkty aktywności ludzkiego umysłu rozwinęły się, aby motywować zachowania adaptacyjne. Ludzie angażują się w sztukę z wielu bezpośrednich powodów - aby wyrazić swoje wewnętrzne ,ja", zademonstrować oddanie bóstwu, zarobić na życie, zapewnić sukces podczas polowania, zadowolić klienta, zaimponować innym, jak również od czasu do czasu dla rozrywki i przyjemności. Można by długo wymieniać tego rodzaju funkcje, czerpiąc przykłady zarówno ze sztuki przeróżnych małych społeczności, jak również analizując teorie estetyczne, niemające wiele wspólnego z wyjaśnieniami biologicznymi czy adaptacyjnymi ${ }^{49}$.

Wiarygodna analiza sztuki przez adaptacjonistów powinna zawierać zatem opis bezpośrednich (bliższych) funkcji sztuki oraz wykazanie tego, jak ewentualnie przyczyniają się one do sukcesu adaptacyjnego lub reprodukcyjnego (wykazanie funkcji ultymatywnych). Nie wydaje się, aby wszystkie wytwory sztuki (ani nawet większość) przyczyniały się do sukcesu adaptacyjnego, tak jak nie przyczyniają się do niego wszystkie odmiany altruizmu czy łączenia się w pary. Jednak wskazanie, jakie funkcje ostateczne stoją za ludzkimi „chceniami”, skłonnościami i emocjonalnymi reakcjami, zbliżyłoby nas do wyjaśnienia, jak dane zachowanie artystyczne (artyfikacyjne) przyczyniło się do sukcesu ewolucyjnego naszych przodków, i dlaczego wraz z nim przetrwało do dziś.

\section{PODSUMOWANIE}

Artykuł pokazuje, jak perspektywa ewolucyjna wpływa na współczesną estetykę. Nie ulega wątpliwości, że akcenty uniwersalistyczne

49 Na temat różnych, nieadaptacyjnych funkcji sztuki por. E. Dissanayake, What is Art For?, Seattle 1988; S. Davies, Aesthetic Judgment, Artworks and Functional Beauty, The Philosophical Quarterly 56(2006), 224-241. 
i naturalistyczne są obecne w samej teorii estetycznej od jej początków. W obliczu współczesnych odkryć naukowych uzyskują one jednak nowy wymiar. Jak pisze Denis Dutton w swym monumentalnym Instynkcie sztuki: „To, czego potrzebuje filozofia sztuki, to podejścia, które zacznie traktować sztukę jako pole działań, obiektów i doświadczeń naturalnie pojawiających się w ludzkim życiu”50. Sztuka $\mathrm{w}$ ujęciu ewolucyjnym przestaje być zatem postrzegana jako nabyta ludzka własność, mająca swe źródło w kulturze, i zaczyna jawić się jako niezbywalna cecha ludzkiego wyposażenia umysłowego, ukształtowana w wyniku działania procesów ewolucyjnych.

Celem artykułu było zwrócenie uwagi na to, że przyjęcie perspektywy uniwersalistycznej i naturalistycznej w estetyce - jak to czyni estetyka ewolucyjna - nie oznacza automatycznie uznania sztuki (lub poszczególnych sztuk) za efekt doboru naturalnego, czy to $w$ postaci adaptacji, czy produktu ubocznego. Nie oznacza też przyjęcia za pewnik w odniesieniu do źródeł sztuki założeń drugiej $\mathrm{z}$ darwinowskich sił ewolucyjnych: doboru płciowego. Podstawowym warunkiem zbadania czy dana cecha lub zachowanie (w tym przypadku: zachowanie artystyczne czy artyfikacyjne) są adaptacyjne w sensie biologicznym (a być może pozostają wyłącznie formą technologii kulturowej) jest odwołanie się do badań empirycznych prowadzonych w oparciu o metody nauk przyrodniczych, a ściślej rzecz biorąc, w oparciu o teorię, sformułowaną po raz pierwszy ponad półtora wieku temu przez Karola Darwina.

W artykule starano się również pokazać, że rzetelnie prowadzone analizy ewolucyjno-estetyczne mają tę cechę, że przede wszystkim właściwie odczytują nienaukowość twierdzeń funkcjonujących w popularnym przekazie, jednocześnie sceptycznie traktując różne wersje hiperadaptacjonizmu w wyjaśnianiu funkcji sztuki, które oparte są zwykle o przesadny optymizm poznawczy pomieszany z luźnym traktowaniem protokołu naukowego. Wagę owego protokolarnego rygoru, którego

50 D. Dutton, dz. cyt., 98. 
utrzymanie wydaje się niezbędne w prowadzeniu badań i analiz ewolucyjnych sztuki, oraz jego prostotę, najlepiej oddaje fragment autorstwa jednej z zajmujących się nimi badaczek: „Teoria doboru naturalnego jest teorią naukową. W związku z tym jej właściwe zastosowanie polega na tworzeniu hipotez w odniesieniu do zjawisk naturalnych, wywodzenie przewidywań z tych hipotez, projektowanie eksperymentów w celu przetestowania tych przewidywań, a następnie poddawanie rezultatów tych eksperymentów analizie ilościowej. Jeśli nie zastosujemy się do tego protokołu, narazimy się na ryzyko rozwijania wyjaśnień post hoc, w których będziemy wybierać tylko te przykłady, które wspierają nasze wyjaśnienie, a ignorować te, które tego nie robią"51.

\section{BIBLIOGRAFIA}

Aiken N.E., The Biological Origins of Art, Praeger, Westport, Connecticut 1998. Allen G., Physiological Aesthetics, H.S. King\&Co., London 1877.

Allen G., The Colour-Sense: Its Origin and Development, Trübner, London 1879.

Bocheński J.M., Przeciw humanizmowi, w: Sens życia i inne eseje, Philed, Kraków 1993, 23-37.

Boyd B., On the Origin of Stories: Evolution, Cognition, and Fiction, Harvard University Press, Cambridge, MA 2009.

Buss D., Psychologia ewolucyjna, tłum. z ang. M. Orski, Gdańskie Wydawnictwo Psychologiczne, Gdańsk 2001.

Cosmides L., Tooby J., Evolutionary Psychology: A Primer, http:// www.psych.ucsb. edu/research/cep/primer.html (dostęp: 28.12.2019).

Cronin H., The Ant and the Peacock: Altruism and Sexual Selection from Darwin to Today, Cambridge University Press, Cambridge 1991.

Cronin H., Zrozumieć naturęcztowieka, w: Nowy Renesans, red. J. Brockman, thum. z ang. P.J. Szwajcer, A.E. Eichler, Wydawnictwo CiS, Warszawa 1996, 59-70.

Darwin K., Dobór ptciowy, tłum. z ang. K. Zaćwilichowska, Państwowe Wydawnictwo Rolnicze i Leśne, Warszawa 1960.

Davies S., Aesthetic Judgment, Artworks and Functional Beauty, The Philosophical Quarterly 56(2006), 224-241.

51 M. Scalise Sugiyama, Carving Art Behavior at the Joints: Symbolic Behavior, Aesthetic Responses, and Artification, ASEBL Journal 11(2015)2, 47. 
Dissanayake E., What is Art For?, University of Washington Press, Seattle 1988.

Dissanayake E., Homo Aestheticus: Where Art Comes From and Why, University of Washington Press, Seattle 1995.

Dissanayake E., The Arts After Darwin. Does Art Have Origin and Adaptive Function w: World Art Studies: Exploring Concepts and Approaches, red. K. Zijlmans, W. van Damme, Valiz, Amsterdam 2008, 241-263.

Dutton D., Instynkt sztuki. Piękno, zachwyt i erwolucja cztowieka, tłum. $\mathrm{z}$ ang. J. Luty, Copernicus Center Press, Kraków 2019.

Grosse E., The Beginnings of Art, D. Appleton and Company, New York - London 1914.

Haddon A.C., Evolution in Art, Charles Scribner's Sons, New York 1914.

Hohol M., Wyjaśnić umyst. Struktura teorii neurokognitywnych, Copernicus Center Press, Kraków 2013

Jan Paweł II, Przestanie do cztonków Papieskiej Akademii Nauk, https://nauka.wiara. pl/doc/469395.Magisterium-Kosciola-wobec-ewolucji (dostęp: 31.01.2020).

Kaleta T., Etologia klasyczna i jej filozoficzne oraz psychologiczne źódta, Życie Weterynaryjne 93(2018)8, 532-536.

Kocur M., Źródta teatru, Wydawnictwo Uniwersytetu Wrocławskiego, Wrocław 2013.

Luty J., Sztuka jako adaptacja. Uniwersalizm w estetyce ewolucyjnej, Wydawnictwo Aureus, Kraków 2018.

Miller G., Umyst w zalotach, tłum. z ang. M. Koraszewska, Dom Wydawniczy Rebis, Poznań 2004.

Miller G., Aesthetic fitness: How sexual selection shaped artistic virtuosity as a fitness indicator and aesthetic preferences as mate choice criteria, Bulletin of Psychology and the Arts, Special issue on evolution, creativity, and aesthetics 2(2001)1, 20-25.

Miłkowski M., Perspektywy erwolucjonistyczne w badaniach spotecznych, w: Oprogramowanie rzeczywistości spotecznej, red. M. Gdula i L.M. Nijakowski, Wydawnictwo Krytyki Politycznej, Warszawa 2014, 185-208.

Parry C.H., The Evolution of the Art of Music, Kegan Paul, London 1896.

Pawłowski B., Adaptacje i ewolucyjna inercja ludzkiego umystu, w: Ewolucja. Filozofia. Religia, red. D. Leszczyński, Oficyna Wydawnicza Atut, Wrocław 2010, 109-121.

Prum R.O., Ewolucja piękna. Jak darwinowska teoria wyboru partnera ksztattuje swiat zwierzat $i$ nas samych, tłum. $\mathrm{z}$ ang. K. Skonieczny, Copernicus Center Press, Kraków 2019.

Scalise Sugiyama M., Carving Art Behavior at the Joints: Symbolic Behavior, Aesthetic Responses, and Artification, ASEBL Journal 11(2015)2, 44-47. 
Sully J., Art and Psychology, Mind 4(1876)1, 467-478.

Tinbergen N., On aims of ethology, Zeitschrift fur Tierpsychologie 20(1963), 410-433.

Trivers R., Parental investment and sexual selection, w: Sexual Selection E the Descent of Man, red. B. Campbell, de Gruyter, New York 1972, 136-179.

Wilson E.O., Konsiliencja. Jedność wiedzy, tłum. z ang. P. Mikos, Zysk i S-ka, Poznań 2002.

Zahavi A., Zahavi A., The Handicap Principle - A Missing Piece of Darwin's Puzzle, Oxford University Press, New York 1997.

\title{
IS AN ADAPTIVE ANALYSIS OF ART POSSIBLE? SOME METHODOLOGICAL ISSUES IN EVOLUTIONARY AESTHETICS
}

\begin{abstract}
Evolutionary aesthetics is a young and promising discipline that still lacks a fully developed methodology, such as neuroaesthetics. The disputes over situations in which a given artistic behaviour could be considered an adaptation (or perhaps a by-product of adaptation or a purely cultural product), do not lead to clear conclusions, as shown by the fact that the test results obtained can often be assigned to many hypothetical functions. For example, even if the hypothesis that a given behaviour is shared by all humans is confirmed empirically, this does not necessarily mean that the behaviour is an adaptation. For an explanation of the evolutionary origin of a behaviour to be reliable, it should pass the Tinbergen (1951) test, and thus get confirmation in each of the following four aspects: (1) it should appear spontaneously at an early stage of individual development, (2) it should have an identified function, (3) it should have its own evolutionary history, and (4) it should comprise an emotional mechanism that causes pleasure or disgust, operating under specific circumstances. If each of these conditions is met, it can be stated with a high degree of certainty that the behaviour in question is an adaptation in the strict sense of the word. But: is accuracy the domain of art?

This article shows that the unique idea of the consilience of the humanities and natural sciences, despite numerous methodological puzzles, offers an attractive interpretation of evolutionary aesthetics from the point of view of contemporary universalist challenges. It also allows us to understand the uniqueness of humans - the only species that artifies, attaches importance to performance, creates art and adores it.
\end{abstract}

Keywords: art, evolution, adaptation, sexual selection, consilience

JERZY LUTY

jerzyluty@gmail.com

ORCID: 0000-0002-2254-9526

DOI: $10.21697 /$ spch.2020.56.1.03 